\title{
Keragaman Populasi F2 Padi (Oryza sativa L.) pada Kondisi Cekaman Suhu Tinggi
}

\section{F2 Population Diversity of Rice (Oryza sativa L.) on High Temperature Stress Condition}

\section{Faradila Median Rini, Desta Wirnas* dan Anggi Nindita}

\author{
Departemen Agronomi dan Hortikultura, Fakultas Pertanian, Institut Pertanian Bogor \\ (Bogor Agricultural University), Jalan Meranti, Kampus IPB Darmaga, Bogor 16680, Indonesia \\ Telp. \& Faks. 0251-8629353 e-mail: agronipb@indo.net.id \\ *Penulis untuk korespondensi : desta.wirnas@yahoo.com
}

Disetujui 20 Agustus 2018 / Published online 3 September 2018

\begin{abstract}
Global warming could imply negative impact on reducing productivity of rice. Plant breeding is expected to produce new varieties of rice that are tolerant to high temperature stress. The purpose of research was to obtain information on variability of character growth of $F 2$ rice genotypes and parents under high temperature stress condition. The experiment was conducted on from February to Juni 2015. About 150 F2 segregants generated trough hybiridization between IPB 4S (sensitive parent) and IR64 (tolerant parent), 20 individuals of IPB 4S, and 20 indiviudals of IR64, were used as genetic materials. All genetic materials were exposed to high temperature stress by growing in a green house of Bogor Agricultural University. The results of mean calculation showed some character of F2 population have better mean value than parental lines. Most of the characters were observed have a high level of diversity caused by segregation of additive, dominant, duplicate epistasis and complementary epistasis genes. Based on the high heritability value and comprehensive coefficient of genetic diversity then the character of panicle length, percentage pithy grain panicle ${ }^{-1}$, and grain weight sample-panicle ${ }^{-1}$ can be used as selection criteria for early generation selection of breeding rice plants which is tolerant of high temperatures. Direct selection based on the number of pithy grain panicle ${ }^{-1}$ with $50 \%$ intensity was able to produce selection differential by $24.7 \%$ on number of pithy grain panicle ${ }^{-1}$ character.
\end{abstract}

Keywords:coefficient of genetic diversity, gene action, heritability, high temperature, selection

\begin{abstract}
ABSTRAK
Pemanasan global menyebabkan dampak negatif, antara lain menurunkan produktivitas padi. Pemuliaan tanaman diharapkan mampu menghasilkan varietas baru tanaman padi yang toleran terhadap cekaman suhu tinggi. Tujuan Penelitian untuk mendapatkan informasi tentang keragaan karakter pertumbuhan genotipe F2 padi dan seluruh tetuanya pada kondisi cekaman suhu tinggi. Penelitian dilaksanakan dari bulan Februari sampai Juni 2015. Materi genetik yang digunakan adalah 150 individu segregan F2 yang berasal dari persilangan IPB 4S dan IR64, 20 individu tetua IPB 4S, 20 individu tetua IR64. Semua materi genetik ditanam dalam kondisi tercekam suhu tinggi di rumah kaca Institut Pertanian Bogor. Hasil perhitungan nilai tengah menunjukan beberapa karakter memiliki nilai tengah lebih baik dibandingkan tetua dan terdapat segregan transgresif. Karakter agronomi yang diamati dikendalikan oleh gen aditif, dominan, epistasis duplikat, dan epistasis komplementer. Berdasarkan nilai heritabilitas yang tinggi dan koefisien keragaman genetik yang luas maka karakter panjang malai, persentase gabah bernas per malai, dan bobot gabah per malai contoh dapat dijadikan kriteria seleksi untuk seleksi generasi awal pemuliaan padi toleran cekaman suhu tinggi. Seleksi langsung berdasarkan jumlah gabah bernas per malai dengan intensitas $50 \%$ menghasilkan diferensial seleksi $24,7 \%$ pada karakter jumlah gabah bernas per malai.
\end{abstract}

Kata kunci: aksi gen, heritabilitas, koefisien keragaman genetik, seleksi, suhu tinggi 


\section{PENDAHULUAN}

Padi (Oryza sativa L.) merupakan sumber bahan pangan utama bagi masyarakat Indonesia. Produksi padi hingga tahun 2013 mengalami kenaikan sebesar 2,62\% dibandingkan pada tahun 2012 atau mencapai 70,86 juta ton gabah kering giling (Kementan, 2013). Seiring dengan bertambahnya jumlah penduduk kebutuhan beras pun meningkat. Hingga tahun 2020 diperkirakan jumlah penduduk Indonesia akan terus bertambah mencapai 271,07 juta jiwa atau meningkat sebesar $5,76 \%$ dibandingkan tahun 2015 (BPS, 2015). Upaya peningkatan hasil terus dilakukan agar kelestarian hasil dapat dicapai. Upaya peningkatan hasil dilakukan dengan menerapkan sistem pengelolaan lahan dan tanaman secara terpadu yang meliputi perbaikan varietas, perbaikan teknologi budidaya, dan lokasi penanaman disesuaikan dengan syarat tumbuh.

Pemanasan global atau Global Warming adalah adanya proses peningkatan suhu rata-rata atmosfer, laut, dan daratan bumi. Menurut Suwedi (2005), terjadinya pemanasan global dapat dipengaruhi oleh adanya aktivitas manusia maupun aktivitas alam itu sendiri (alamiah). Aktivitas manusia yang diperkirakan berkontribusi pada kenaikan suhu bumi antara lain adalah aktivitas yang meningkatkan konsentrasi gas rumah kaca (GRK) maupun aktivitas yang mempercepat terjadinya penipisan lapisan ozon. Meningkatnya kandungan GRK menimbulkan efek GRK di atmosfer. Efek GRK ini menyerap radiasi gelombang panjang yang menyebabkan suhu bumi meningkat (Subagyono dan Surmaini, 2007).

IPCC memprediksi peningkatan temperatur rata-rata global akan meningkat 1,1 hingga $6,4{ }^{\circ} \mathrm{C}\left(2,0\right.$ hingga $\left.11,5{ }^{\circ} \mathrm{F}\right)$ antara tahun 1990 dan 2100 (IPCC, 2007). Kenaikan suhu bumi tersebut dapat menjadi faktor pembatas dalam budidaya tanaman padi. Cekaman suhu tinggi merupakan salah satu cekaman lingkungan abiotik yang mengakibatkan penurunan produktivitas tanaman. Tanaman mengalami cekaman suhu tinggi apabila kondisi suhu yang diterima melebihi suhu optimum yang dibutuhkan tanaman tersebut (Kotak et al., 2007). Wahid et al., (2007) menyebutkan bahwa cekaman suhu tinggi pada tanaman secara umum berpengaruh terhadap proses fisiologis, seperti fotosintesis, respirasi, kandungan air, dan stabilitas membran. Tschirley (2007) memperkirakan penurunan hasil pada tanaman padi dapat mencapai lebih dari $20 \%$ apabila suhu naik lebih dari $4^{\circ} \mathrm{C}$. Peng et al. (2004) dalam penelitiannya menyebutkan bahwa setiap kenaikan suhu minimum $1^{\circ} \mathrm{C}$ akan menurunkan hasil padi sebesar $10 \%$.

Salah satu usaha mitigasi kondisi peningkatan suhu muka bumi adalah dengan menanam varietas toleran suhu tinggi yang dapat diperoleh melalui pemuliaan tanaman. Pemuliaan tanaman dapat dilakukan melalui penggabungan sifat-sifat genetik melalui persilangan yang dilanjutkan dengan seleksi dan evaluasi daya hasil. Bahan pemuliaan dapat berasal dari varietas-varietas lokal, varietas liar, varietas introduksi dari mencanegara ataupun galur-galur homozigot (Kasno, 1992).

\section{BAHAN DAN METODE}

Penelitian ini dilaksanakan pada bulan Februari sampai Juni 2015. Penelitian dilakukan di rumah kaca Kebun Percobaan University Farm IPB, Cikabayan, Dramaga, Bogor. Pengeringan dan pengamatan pasca panen dilakukan di Laboratorium Pemuliaan Tanaman Departemen Agronomi dan Hortikultura, Fakultas Pertanian, Institut Pertanian Bogor.

Bahan tanam yang digunakan adalah benih P1 (IPB 4S) ditanam sebanyak 20 individu, P2 (IR64) ditanam sebanyak 20 individu, dan F2 hasil kombinasi persilangan IPB 4S x IR64 ditanam sebanyak 250 individu. Media tanam yang digunakan merupakan campuran tanah dan pupuk kandang dengan perbandingan 2:1. Pupuk dasar yang diberikan adalah pupuk Urea, $\mathrm{KCl}, \mathrm{SP}-36$ dengan masingmasing dosis $250 \mathrm{~kg}$ Urea ha ${ }^{-1}, 200 \mathrm{~kg} \mathrm{KCl}$ $\mathrm{ha}^{-1}, \quad 100 \mathrm{~kg}$ SP-36 ha $\mathrm{ha}^{-1}$, Pestisida yang digunakan adalah insektisida karbofuran $3 \mathrm{G}$ dengan dosis $21 \mathrm{ha}^{-1}$, dan pestisida dengan bahan aktif Imidakloprid 5\% dengan dosis $0,6 \mathrm{~kg} \mathrm{ha}^{-1}$. Alat-alat yang akan digunakan adalah alat-alat budidaya pertanian, termometer maksimumminimum, ember ukuran 5 liter, bak plastik penyemaian, label, amplop, alat tulis, plastik, counter, timbangan digital, timbangan analitik, meteran, dan oven.

Penelitian dilakukan melalui beberapa tahapan kegiatan. Persiapan media tanam dilakukan dengan mengisi ember plastik dengan campuran tanah dan pupuk kandang dengan perbandingan 2:1. Penyemaian yaitu benih disemai pada bak plastik di tempat persemaian dengan media tanam berupa tanah dan pupuk kandang dengan perbandingan 1:1. Bibit hasil persemaian dipindah tanam setelah berumur 14 hari ke dalam media tanam dalam ember. Bibit persemaian ditanam satu bibit per ember. Pemupukan dilakukan sebanyak dua kali yaitu pada 1 MST dengan dosis $125 \mathrm{~kg}$ Urea ha ${ }^{-1}, 200$ kg SP-36 ha ${ }^{-1}$, dan $100 \mathrm{~kg} \mathrm{KCl} \mathrm{ha}{ }^{-1}$ serta pada 3 MST dengan dosis urea sebanyak $125 \mathrm{~kg}$ Urea 
ha $^{-1}$. Awal tanam hingga berumur 45 HST, tanaman berada pada lantai jemur dengan kondisi suhu lingkungan. Kondisi air dijaga dengan menggenangkan air $\pm 5 \mathrm{~cm}$ pada media tanam dalam ember selama awal tanam hingga tanaman memasuki awal panen. Pada saat 45 HST sampai panen, tanaman berada dalam rumah kaca dengan kondisi tercekam suhu tinggi. Pengendalian hama tanaman dikendalikan secara kimia dengan insektisida.

Kegiatan panen dilakukan dengan cara potong atas menggunakan sabit saat $80 \%$ malai telah menguning. Penanganan pasca panen yang dilakukan adalah penjemuran, perontokan, pemisahan gabah bernas dan hampa, perhitungan dan penimbangan gabah padi. Gabah padi yang telah dijemur kemudian dirontokan dan dipisahkan antara gabah bernas dan gabah hampa. Gabah padi yang telah terpisah dimasukkan kedalam amplop cokelat dan di oven dengan suhu $37^{\circ} \mathrm{C}$ selama 24 jam. Perhitungan gabah dilakukan secara manual dan penimbangan bobot gabah dilakukan menggunakan timbangan analitik.

Pengamatan akan dilakukan terhadap karakter agronomi yang dimiliki tanaman padi. Karakter agronomi tersebut antara lain : tinggi tanaman 45 HST $(\mathrm{cm})$, tinggi tanaman 90 HST (cm), jumlah anakan 45 HST, jumlah anakan 90 HST, Jumlah anakan produktif, panjang malai $(\mathrm{cm})$, jumlah gabah bernas per malai, jumlah gabah hampa per malai, jumlah gabah total per malai, persentase gabah bernas per malai, bobot 100 butir (g), bobot gabah bernas per malai contoh, dan bobot gabah bernas per tanaman $(\mathrm{g})$.

Analisis data yang dilakukan pada penelitian ini adalah perhitungan nilai tengah dan standar deviasi masing-masing peubah pada tiap populasi, keragaan genetik masing-masing karakter, heritabilitas arti luas, koefisien keragaman genetik, pendugaan aksi gen menggunakan analisis skewness dan kurtosis dan koefisien korelasi. Perangkat lunak yang digunakan adalah Microsoft Excel 2007, STAR IRRI, dan SPSS.

\section{HASIL DAN PEMBAHASAN}

\section{Kondisi Umum}

Pertumbuhan tanaman padi dibagi ke dalam tiga fase yaitu: vegetatif (awal pertumbuhan sampai pembentukan bakal malai/primordia), reproduktif (primordia sampai pembungaan), pematangan (pembungaan sampai gabah matang) (Makarim et al., 2009). Pada percobaan kali ini pengukuran suhu dilakukan sejak tanaman memasuki masa vegetatif akhir hingga panen. Suhartatik et al. (2008) menyatakan suhu udara yang tinggi $\left(38-40^{\circ} \mathrm{C}\right)$ pada fase vegetatif diperlukan untuk merangsang pembentukan anakan, sedangkan dari fase pengisian gabah sampai panen diperlukan udara yang sejuk $\left(23^{\circ} \mathrm{C}\right)$. Suhu maksimum dan minimum selama pertumbuhan tanaman diukur untuk mengetahui suhu rumah kaca dan suhu di lapang setiap hari (Gambar 1).

Awal tanam (12 Februari) hingga tanaman mencapai umur tanamn 71 HST tanaman diletakkan pada lantai jemur. Selama fase vegetatif akhir (55-70 HST) pengukuran suhu harian menunjukkan rata rata suhu maksimum berkisar antara $28-34^{\circ} \mathrm{C}$, sedangkan suhu minimum berkisar antara $20-23^{\circ} \mathrm{C}$. Memasuki fase generatif yaitu pada 71 HST tanaman dipindahkan ke dalam rumah kaca untuk mendapatkan perlakuan suhu tinggi, namun pertumbuhan tanaman padi mengalami gangguan berat akibat serangan hama sehingga dipandahkan dari rumah kaca pada saat padi berumur 95 HST untuk menghindari tanaman tertular tanaman lain yang telah terserang hama. Selama penanaman di rumah kaca, pengukuran suhu harian menunjukkan rata-rata suhu maksimum berkisar antara $31-45^{\circ} \mathrm{C}$ sedangkan rata-rata suhu minimum berkisar antara $20-24^{\circ} \mathrm{C}$. Suhu lingkungan pertumbuhan padi pada umur $95 \mathrm{HST}$ hingga panen berkisar antara $29-38^{\circ} \mathrm{C}$ (maksimum) dan $20-23^{\circ} \mathrm{C}$ (minimum).

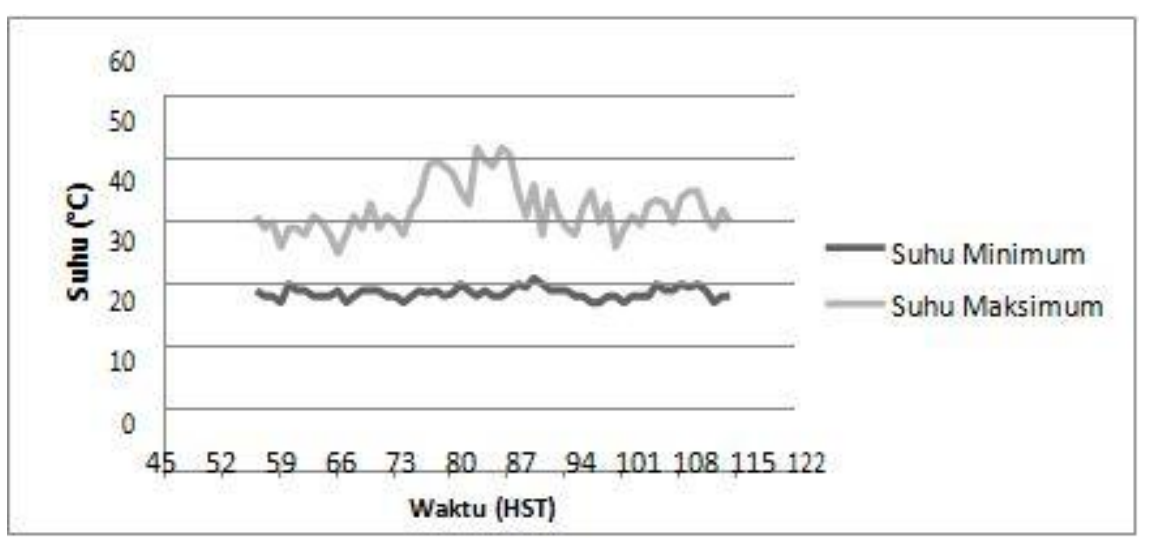

Gambar1. Suhu minimum dan maksimum selama penelitian 
Pertumbuhan Pertumbuhan tanaman padi mengalami gangguan berat akibat serangan hama pada fase generatif. Hal ini disebabkan hama yang menyerang tanaman padi mudah menulari tanaman yang lain pada kondisi terisolasi di dalam rumah kaca dengan kelembapan yang tinggi. Kelembapan udara rata-rata selama penelitian berlangsung yaitu sejak Februari 2015 hingga Juni 2015 adalah sebesar 85\% (BMKG, 2015). Hama yang menyebar diantaranya; kepik penghisap bulir padi (Nezara viridula), belalang (Valanga nigricornis), wereng cokelat (Nilaparvata lugens), dan walang sangit (Leptocorisa spp.). Penyemprotan pestisida dilakukan mulai 8 MST hingga 14 MST yang dilakukan tiap satu minggu sekali. Gejala serangan fisiologis yang terjadi menunjukkan beberapa genotipe kekurangan unsur nitrogen/klorosis.

\section{Keragaan Tanaman}

Nilai tengah dan simpangan baku P1, P2, dan F2 pada persilangan IPB 4S dan IR64 disajikan pada Tabel 1. Berdasarkan hasil analisa data diketahui bahwa karakter populasi F2 berupa tinggi tanaman 90 HST, jumlah gabah bernas per malai, persentase gabah bernas per malai, bobot gabah bernas per malai contoh, dan bobot gabah bernas per tanaman memiliki nilai tengah yang lebih tinggi dibandingkan kedua tetuanya. Keragaman yang besar pada karakter populasi F2 tersebut memberi keuntungan dalam proses pemuliaan tanaman untuk mendapatkan genotipe yang unggul. Abdullah et al., (2008) menyatakan bahwa potensi hasil padi ditentukan oleh komponen hasil yaitu jumlah malai per rumpun, jumlah gabah per malai, persentase gabah isi, dan bobot gabah bernas.

Nilai Tengah karakter F2 yang lebih tinggi dibandingkan dengan tetuanya menunjukan bahwa terdapat segregan-segregan potensial yang memiliki keragaan yang lebih baik dibandingkan kedua tetuanya. Menurut Poehlman dan Sleper (1996) segregan transgresif merupakan genotipe dari hasil persilangan dua tetua yang memiliki segregasi gen pada sifat-sifat kuantitatif yang jangkauan sebarannya melampaui jangkauan sebaran kedua tetuanya. Simpangan baku karakter populasi F2 memiliki nilai lebih besar daripada tetuanya kecuali pada karakter jumlah anakan 45 HST, jumlah anakan 90 HST dan jumlah anakan produktif. Tingginya simpangan baku ini menunjukkan adanya keragaman genetik pada populasi kedua zuriat hasil persilangan.

Tabel 1. Nilai rata-rata dan simpangan baku karakkter agronomi padi F2 dan tetuanya

\begin{tabular}{lrrc}
\hline Karakter & \multicolumn{1}{c}{ P1 } & P2 & F2 \\
\hline Tinggi Tanaman 45 HST $(\mathrm{cm})$ & $108,6 \pm 5,4$ & $81,3 \pm 7,2$ & $108,3 \pm 15,1$ \\
Tinggi Tanaman 90 HST (cm) & $123,6 \pm 4,2$ & $102,1 \pm 5,9$ & $133,3 \pm 19,2$ \\
Jumlah Anakan 45 HST & $13,7 \pm 2,3$ & $23,9 \pm 6,6$ & $23,1 \pm 4,6$ \\
Jumlah Anakan 90 HST & $16,9 \pm 3,2$ & $27,6 \pm 5,5$ & $21,1 \pm 4,6$ \\
Jumlah Anakan Produktif & $12,7 \pm 2,9$ & $23,1 \pm 5,7$ & $17,6 \pm 5,1$ \\
Panjang Malai (cm) & $27,0 \pm 1,9$ & $23,2 \pm 0,8$ & $23,0 \pm 1,9$ \\
Jumlah Gabah Bernas Malai-1 & $22,4 \pm 12,8$ & $25,4 \pm 11,3$ & $53,3 \pm 38,3$ \\
Jumlah Gabah Hampa Malai-1 & $165,8 \pm 33,0$ & $90,8 \pm 15,8$ & $88,0 \pm 34,3$ \\
Jumlah Gabah Total Malai-1 & $184,4 \pm 34,3$ & $116,2 \pm 11,6$ & $140,1 \pm 41,2$ \\
Presentase Gabah Bernas Malai-1 & $0,1 \pm 0,1$ & $0,2 \pm 0,1$ & $0,4 \pm 0,2$ \\
Bobot 100 Butir (g) & $1,8 \pm 0,2$ & $1,7 \pm 0,2$ & $1,6 \pm 0,3$ \\
Bobot Gabah Bernas Malai Contoh-1 (g) & $1,6 \pm 1,1$ & $2,1 \pm 1,2$ & $3,9 \pm 2,4$ \\
Bobot Gabah Bernas Tanaman-1 (g) & $4,2 \pm 3,8$ & $9,6 \pm 5,4$ & $14,5 \pm 9,7$ \\
\hline
\end{tabular}

Karakter tinggi tanaman 45 HST, jumlah anakan 45 HST, jumlah anakan 90 HST, jumlah anakan produktif, dan jumlah gabah total per malai memiliki nilai tengah diantara nilai tengah kedua tetuanya dan hanya karakter jumlah gabah hampa per malai dan bobot 100 butir yang memiliki nilai tengah dibawah nilai tengah kedua tetuanya. Nilai tengah yang lebih tinggi maupun lebih rendah pada populasi F2 disebabkan terjadinya segregasi dan rekombinasi gen akibat dari persilangan antara kedua tetua yang menghasilkan fenotipe yang berbeda dibandingkan dengan kedua tetuanya.

\section{Pendugaan Jumlah Gen dan Aksi Gen}

Program pemuliaan tanaman salah satunya bertujuan untuk mendapatkan karakter kuantitatif dengan hasil yang tinggi. Menurut Fehr (1987) karakter kuantitatif dikendalikan oleh banyak gen dan pengaruh masing-masing gen terhadap penampilan karakter (fenotipe) lebih kecil dan bersifat aditif, walaupun gen-gen tersebut secara bersama-sama mempunyai pengaruh yang lebih besar dari pengaruh lingkungan. Analisis sebaran data pada populasi F2 bertujuan untuk menduga sifat suatu karakter apakah kualitatif (dikendalikan oleh gen-gen mayor) atau kuantitatif (dikendalikan oleh gengen minor atau poligenik), aditif, atau ada 
tidaknya epistasis (Manalu, 2016). Analisis skewness dan kurtosis dapat digunakan untuk menentukan kemungkinan bentuk aksi gen dan banyaknya gen yang terlibat dalam mengendalikan keragaan suatu sifat kuantitatif (Roy, 2000).

Tabel 2 menunjukkan keberagaman jumlah gen adiktif maupun aksi gen yang terlibat pada masing- masing karakter populasi F2. Karakter tinggi tanaman 45 HST, jumlah anakan 45 HST, jumlah anakan 90 HST, jumlah anakan produktif, panjang malai, dan jumlah gabah hampa per malai memiliki segregasi gen adiktif yang sedikit dan dikendalikan oleh aksi gen epistatis duplikat. Karakter tinggi tanaman 90 HST, jumlah gabah bernas per malai, jumlah gabah total per malai dan bobot 100 butir dikendalikan oleh aksi gen epistasis komplementer dengan segregasi gen adiktif yang sedikit. Kuswanto et al. (2004) menyatakan bahwa epistasis adalah peristiwa dimana satu atau sepasang gen menutupi atau mengalahkan ekspresi gen lain yang bukan alelnya . Epistasis dominan terjadi bila interaksi dua gen membentuk fenotipe yang sama dan epistasis kompelemnter dimana fungsi suatu gen akan diperlukan gen lain dalam suatu proses metabolisme (Griffiths et al., 2005).

Jumlah gabah hampa per malai merupakan satu-satunya karakter yang dikendalikan oleh aksi gen epistasis adiktif dengan banyak gen adiktif yang terlibat. Karakter persentasi gabah bernas per malai, bobot gabah bernas per malai contoh dan bobot gabah bernas per tanaman memiliki segregasi gen adiktif yang banyak dengan melibatkan aksi gen dominan yang menjulur ke kiri. Aksi gen adiktif merupakan efek kumulatif dari seluruh alel dalam menghasilkan suatu fenotipe sedangkan aksi gen dominan adalah interaksi antar alel, apabila suatu sifat dikendalikan oleh aksi gen dominan maka baik individu homozigot maupun heterozigot akan menampilkan fenotipe yang sama (Holland, 2011). Karakter yang dikendalikan oleh banyak aksi gen adiktif adalah karakter yang potensial untuk dipilih dalam kegiatan seleksi (Jambormias, 2014).

Tabel 2. Jumlah gen adiktif dan aksi gen pada pola sebaran F2 hasil persilangan IPB45 dan IR64

\begin{tabular}{lrrrrrrrc}
\hline Karakter & S & SES & \multicolumn{1}{c}{ Zs } & \multicolumn{1}{c}{ K } & SEK & Zk & $\sum$ Gen & Aksi Gen \\
\hline Tinggi Tanaman 45 HST (cm) & $-2,36$ & 0,22 & $-10,84^{* *}$ & 12,96 & 0,43 & $29,92^{* *}$ & Sd & ED \\
Tinggi Tanaman 90 HST (cm) & 0,94 & 0,22 & $4,32^{* *}$ & 8,60 & 0,43 & $19,87^{* *}$ & Sd & EK \\
Jumlah Anakan 45 HST & 0,29 & 0,22 & 1,31 tn & 4,67 & 0,43 & $10,79^{* *}$ & Sd & ED \\
Jumlah Anakan 90 HST & $-0,32$ & 0,22 & $-1,44$ tn & 2,09 & 0,43 & $4,82^{* *}$ & Sd & ED \\
Jumlah Anakan Produktif & $-1,42$ & 0,22 & $-6,52^{* *}$ & 2,84 & 0,43 & $6,57^{* *}$ & Sd & ED \\
Panjang Malai (cm) & $-0,90$ & 0,22 & $-4,12^{* *}$ & 2,04 & 0,43 & $4,70^{* *}$ & Sd & ED \\
Jumlah Gabah Bernas Malai-1 & 3,40 & 0,22 & $15,57^{* *}$ & 18,81 & 0,43 & $43,44^{* *}$ & Sd & EK \\
Jumlah Gabah Hampa Malai-1 & $-0,28$ & 0,22 & $-1,30$ tn & $-0,68$ & 0,43 & $-1,58$ tn & Ba & AD \\
Jumlah Gabah Total Malai-1 & 1,82 & 0,22 & $8,33^{* *}$ & 7,95 & 0,43 & $18,35^{* *}$ & Sd & EK \\
Presentase Gabah Bernas Malai-1 & 0,45 & 0,22 & $2,07^{*}$ & $-0,32$ & 0,43 & $-0,75$ tn & Ba & DM \\
Bobot 100 Butir (g) & 0,76 & 0,24 & $3,22^{* *}$ & 3,07 & 0,47 & $6,56^{* *}$ & Sd & EK \\
Bobot Gabah Bernas Malai Contoh-1 (g) & 0,47 & 0,22 & $2,17^{*}$ & $-0,42$ & 0,43 & $-0,97 \mathrm{tn}$ & Ba & DM \\
Bobot Gabah Bernas Tanaman -1 $(\mathrm{g})$ & 0,61 & 0,22 & $2,80^{* *}$ & $-0,03$ & 0,43 & $-0,07 \mathrm{tn}$ & Ba & DM \\
\hline
\end{tabular}

Keterangan : **berbeda nyata pada taraf $1 \%$; *berbeda nyata pada taraf $5 \%$; ${ }^{\mathrm{tn}}$ tidak berbeda nyata pada taraf 5\%; S: skewness; SES: standard error skewness; ZS: statistik uji skewness; K: kurtosis; SEK: standard error kurtosis; $\mathrm{ZK}_{\mathrm{K}}$ : statistik uji kurtosis; Sd: dikendalikan sedikit gen; Ba: dikendalikan banyak gen; Ad: hanya aditif; EK: epistasis komplementer; EA: epistasis aditif; ED: epistasis duplikatif; DM: dominan.

\section{Heritabilitas}

Heritabilitas merupakan perbadingan antara ragam genotipe dan total ragam fenotipe dari suatu karakter yang menggambarkan besarnya kontribusi genetik pada suatu Karakter. Heritabilitas dibedakan menjadi heritabilitas arti luas dan heritabilitas arti sempit (Syukur et al., 2010). Klug dan Cummings (2005) menyatakan bahwa heritabilitas dalam arti luas mengukur proporsi ragam fenotipe yang disebabkan oleh variasi genetik bagi populasi tunggal pada lingkungan yang terbatas selama penelitian. Nilai heritabilitas dikatakan tinggi apabila nilai $>50 \%$, sedang apabila nilai $20-50 \%$ dan rendah apabila nilai <20\% (Standfield, 1991).

Berdasarkan analisis data menunjukkan bahwa karakter populasi F2 berupa jumlah anakan 45 HST dan jumlah anakan produktif memiliki nilai heritabilitas yang sedang sedangkan karakter jumlah anakan 90 HST dan bobot 100 butir memiliki nilai heritabilitas yang rendah. Nilai heritabilitas yang rendah artinya karakter ini lebih dipengaruhi lingkungan. Hal ini dikarenakan di area penelitian terdapat gangguan suhu yang tinggi dan serangan hama yang mengganggu fase pematangan sampai menjelang panen. 
Karakter tinggi tanaman 45 HST, tinggi tanamn 90 HST, panjang malai, jumlah gabah bernas per malai, jumlah gabah hampa per malai, jumlah gabah total per malai, persentase gabah bernas per malai, bobot gabah bernas per malai contoh dan bobot gabah bernas per tanaman memiliki nilai heritabilitas yang tinggi. Aryana (2007) menyatakan bahwa nilai heritabilitas yang tinggi sangat berperan dalam meningkatkan efektifitas seleksi karena pengaruh lingkungan kecil, sehingga faktor genetik lebih dominan dalam penampilan genetik tanaman.

Koefisien keragaman genetik digunakan untuk menduga luas atau tidaknya keragaman genetik yang dimiliki masing-masing karakter (Puspitasari, 2011). Alnopri (2004) menyatakan bahwa nilai koefisien keragaman genetik (KKG) yang digunakan dibagi menjadi tiga, yaitu : sempit $0-10 \%$, sedang $10-20 \%$, dan luas $>20 \%$. Karakter jumlah anakan 45 HST, dan jumlah anakan produktif memiliki kategori KKG yang sedang. Karakter tinggi tanaman 45 HST, tinggi tanaman 90 HST, Jumlah anakan 90 HST, jumlah gabah bernas per malai, jumlah gabah hampa per malai, jumlah gabah total per malai, dan bobot gabah bernas per tanaman memiliki nilai KKG yang sempit. Nilai KKG yang sempit memiliki keragaman yang rendah atau cenderung homogen sehingga menyulitkan dalam kegiatan seleksi.

Karakter yang memiliki nilai KKG luas adalah panjang malai, persentasi gabah bernas, bobot 100 butir, dan bobot gabah bernas per malai. KKG yang luas mengindikasikan bahwa karakter tersebut heterogen atau keragamannya tinggi sehingga akan memudahkan dalam kegiatan seleksi karena lebih efektif sebab seleksi terhadap karakter kuantitatif dapat dilakukan tanpa mengabaikan nilai tengah populasi yang bersangkutan (Febrianto et al., 2015).

Tabel 3. Nilai duga komponen ragam, heritabilitas arti luas dan koefisien keragaan genetik karakter agronomi padi F2 dan tetuanya

\begin{tabular}{lrrrcc}
\hline \multicolumn{1}{c}{ Karakter } & \multicolumn{1}{c}{$\sigma_{2} \mathrm{p}$} & \multicolumn{1}{c}{$\sigma_{2} \mathrm{e}$} & \multicolumn{1}{c}{$\sigma_{22} \mathrm{~g}$} & $\mathrm{H}_{2 \mathrm{bs}}(\%)$ & $\mathrm{KKG}(\%)$ \\
\hline Tinggi Tanaman 45 HST $(\mathrm{cm})$ & 226,6 & 38,6 & 188,0 & 83 & 6 \\
Tinggi Tanaman 90 HST (cm) & 366,8 & 24,5 & 342,3 & 93 & 5 \\
Jumlah Anakan 45 HST & 21,1 & 15,0 & 6,1 & 29 & 12 \\
Jumlah Anakan 90 HST & 21,4 & 17,7 & 3,6 & 17 & 9 \\
Jumlah Anakan Produktif & 25,6 & 16,3 & 9,3 & 36 & 12 \\
Panjang Malai $(\mathrm{cm})$ & 3,5 & 1,5 & 2,0 & 56 & 40 \\
Jumlah Gabah Bernas Malai-1 & 1465,6 & 145,5 & 1320,1 & 90 & 2 \\
Jumlah Gabah Hampa Malai-1 & 1174,2 & 523,0 & 651,2 & 55 & 2 \\
Jumlah Gabah Total Malai-1 & 1696,8 & 399,3 & 1297,5 & 76 & 2 \\
Presentase Gabah Bernas Malai-1 & 0,0 & 0,0 & 0,0 & 84 & 454 \\
Bobot 100 Butir (g) & 0,1 & 0,1 & 0,0 & 13 & 185 \\
Bobot Gabah Bernas Malai Contoh-1 $(\mathrm{g})$ & 5,4 & 1,3 & 4,1 & 75 & 37 \\
Bobot Gabah Bernas Tanaman -1 $(\mathrm{g})$ & 92,7 & 20,8 & 71,8 & 78 & 9 \\
\hline Keban & $\sigma 2 p$ : &
\end{tabular}

Keterangan : $\quad \sigma 2 p$ : ragam fenotipe; $\sigma 2 e$ : ragam lingkungan; $\sigma 2 g$ : ragam genetik; H2bs : heritabilitas arti luas; KKG : koefisien keragaman genetik.

\section{Analisis Korelasi antar Karakter}

Korelasi antar karakter fenotipe diperlukan dalam seleksi tanaman, untuk mengetahui karakter yang dapat dijadikan petunjuk seleksi terhadap produktivitas yang tinggi (Wirnaset al., 2006). Korelasi merupakan angka yang menunjukkan arah dan kuatnya hubungan antar variabel atau lebih yang dinyatakan dalam bentuk hubungan positif atau negatif, sedangkan kuatnya hubungan dinyatakan dalam besarnya koefisien korelasi (Haryono, 2001).

Menurut Nasution dan Suhartini (1991), potensi hasil pada tanaman padi yang dibentuk selama pertumbuhan sangat ditentukan oleh komponen hasil seperti jumlah gabah hampa per malai, jumlah malai dan bobot 100 butir. Sedangkan menurut Rusdi dan Bahar (1999), tinggi tanaman, jumlah gabah per malai, gabah bernas, berat 100 butir biji berkorelasi nyata dengan hasil gabah. Penelitian ini menggunakan karakter bobot gabah bernas per tanaman sebagai karakter penting dalam menentukan hubungan antar karakter.

Koefisien korelasi antar karakter populasi F2 disajikan pada tabel 4. Hasil analisis korelasi

menunjukan bahwa karakter berupa tinggi tanaman 45 HST, tinggi tanaman 90 HST berkorelasipositif dan sangat nyata terhadap bobot gabah bernas per tanaman. Hal ini mengindikasikan bahwa peningkatan tinggi tanaman sampai batas tertentu akan diikuti dengan peningkatan hasil. Hasil yang sama juga diperoleh dalam penelitian Limbongan (2008) meskipun tetap diperlukan tinggi tanaman ideal dengan hasil bobot gabah yang terbaik dalam melakukan 
seleksi sebab tanaman tinggi akan mudah rebah sehingga dapat menurunkan hasil.

Karakter jumlah anakan produktif, jumlah gabah bernas per malai, persentase gabah bernas per malai, bobot 100 butir dan bobot gabah bernas per malai contoh juga memiliki korelasi positif yang sangat nyata terhadap bobot gabah bernas per tanaman. Selain itu karakter jumlah gabah total per malai memiliki korelasi nyata bernilai positif terhadap bobot gabah bernas per tanaman. Artinya seleksi terhadap bobot gabah bernas per tanaman dapat meningkatkan jumlah anakan produktif, jumlah gabah bernas per malai, persentase gabah bernas per malai, bobot 100 butir, bobot gabah bernas per malai contoh maupun jumlah gabah total per malai.

Korelasi negatif dan sangat nyata terhadap bobot gabah bernas per tanaman ditunjukkan oleh karakter jumlah gabah hampa per malai yang artinya semakin tinggi bobot gabah bernas per tanaman maka jumlah gabah hampa per malai akan semakin sedikit. Tidak adanya korelasi antara jumlah anakan 45 HST, jumlah anakan 90 HST dan panjang malai menunjukkan bahwa peningkatan maupun penurunan pada bobot gabah bernas per tanaman tidak berhubungan dengan peningkatan maupun penurunan pada jumlah anakan $45 \mathrm{HST}$, jumlah anakan 90 HST dan panjang malai.

Tabel 4. Korelasi linier antar karakter kuantitatif populasi F2 tanaman padi

\begin{tabular}{|c|c|c|c|c|c|c|c|c|c|c|c|}
\hline & TT45 & TT90 & JA45 & JA90 & AP & PM & GB & $\mathrm{GH}$ & $\mathrm{BT}$ & $\mathrm{PB}$ & SBT \\
\hline TT90 & $0,69 * *$ & & & & & & & & & & \\
\hline JA45 & $-0,10 \mathrm{tn}$ & $-0,04 \mathrm{tn}$ & & & & & & & & & \\
\hline JA90 & $-0,13 \operatorname{tn}$ & $-0,05 \mathrm{tn}$ & $0,63 * *$ & & & & & & & & \\
\hline $\mathrm{AP}$ & $-0,15 \mathrm{tn}$ & $-0,15 \mathrm{tn}$ & $0,37 * *$ & $0,46^{* *}$ & & & & & & & \\
\hline PM & $0,22 * *$ & 0,14 tn & $-0,28 * *$ & $0,04 \mathrm{tn}$ & $0,05 \mathrm{tn}$ & & & & & & \\
\hline GB & $0,26 * *$ & $0,40 * *$ & $0,01 \mathrm{tn}$ & $0,00 \mathrm{tn}$ & $0,09 \mathrm{tn}$ & $0,08 \mathrm{tn}$ & & & & & \\
\hline $\mathrm{GH}$ & $0,01 \mathrm{tn}$ & $-0,15 \mathrm{tn}$ & $-0,24 * *$ & $-0,07 \mathrm{tn}$ & $-0,06 \mathrm{tn}$ & $0,55 * *$ & $-0,41 * *$ & & & & \\
\hline BT & $0,24 * *$ & $0,21 * *$ & $-0,20^{*}$ & $-0,04 \mathrm{tn}$ & $0,06 \mathrm{tn}$ & $0,62 * *$ & $0,49 * *$ & $0,58 * *$ & & & \\
\hline PB & $0,23 * *$ & $0,41 * *$ & $0,09 \mathrm{tn}$ & $-0,00 \mathrm{tn}$ & $0,06 \mathrm{tn}$ & $-0,16^{*}$ & $0,77 * *$ & $-0,79 * *$ & $-0,06 \mathrm{tn}$ & & \\
\hline SBT & $0,06 \mathrm{tn}$ & $0,05 \mathrm{tn}$ & $-0,26 * *$ & $-0,12 \mathrm{tn}$ & $-0,01 \mathrm{tn}$ & $0,18 \mathrm{tn}$ & $0,18^{*}$ & $-0,25 * *$ & $-0,04 \mathrm{tn}$ & $0,27 * *$ & \\
\hline BMC & $0,31 * *$ & $0,43 * *$ & $0,05 \mathrm{tn}$ & $-0,01 \mathrm{tn}$ & $0,19 *$ & $0,07 \mathrm{tn}$ & $0,72 * *$ & $-0,52 * *$ & $0,16^{*}$ & $0,83 * *$ & $0,48 * *$ \\
\hline BPT & $0,25^{* *}$ & $0,34 * *$ & 0,14 tn & $0,10 \operatorname{tn}$ & $0,41 * *$ & $0,08 \mathrm{tn}$ & $0,65 * *$ & $-0,45^{* *}$ & $0,18^{*}$ & $0,73 * *$ & $0,40 * *$ \\
\hline
\end{tabular}

Keterangan: **berbeda nyata pada taraf $1 \%$; *berbeda nyata pada taraf 5\%; tntidak berbeda nyata pada taraf 5\%;TT45 : tinggi tanaman 45 HST; TT90 : tinggi tanaman 90 HST; JA45 : jumlah anakan 45 HST; JA90 : jumlah anakan 90 HST; AP :jumlah anakan produktif; PM: panjang malai; GB : jumlah gabah bernas per malai; GH : jumlah gabah hampa per malai; BT : jumlah gabah bernas total per malai; SBT : bobot 100 butir; BMC : bobot gabah bernas per malai contoh; BPT :bobot gabah bernas per tanaman.

Seleksi

Seleksi dalam pemuliaan tanaman bertujuan untuk mendapatkan varietas ungul melalui proses pemilihan individu atau kelompok dari suatu populasi. Syukur et al., (2015) menyebutkan bahwa terdapat dua bentuk seleksi untuk meningkatkan karakter tanaman, yaitu seleksi antara populasi yang sudah ada untuk menciptakan karakter yang diinginkan dan seleksi dalam populasi untuk memperoleh tanaman yang digunakan untuk menciptakan varietas baru berupa keturunan hasil persilangan yang terdiri dari atas tanaman hasil segregasi.
Karakter yang dipilih sebagai kriteria seleksi adalah karakter bobot gabah bernas per tanaman. Karakter tersebut merupakan karkater utama dari daya hasil, selain itu karakter tersebut memiliki aksi gen aditif, nilai heritabilitas yang tinggi dan nilai koefisien keragaman genetik yang luas. Populasi F2 adalah populasi dengan keadaan segregasi yang tinggi sehingga memungkinkan untuk didapatkannya genotipe-genotipe potensial dengan daya hasil yang tinggi (Syukur et al., 2015). Oleh sebab itu dalam penelitian ini dilakukan intensitas seleksi terhadap $50 \%$ tanaman terbaik dari populasi F2. 
Tabel 5. Nilai differensial hasil seleksi berdasarkan karakter jumlah gabah bernas per malai

\begin{tabular}{lccc}
\hline Karakter & $\begin{array}{c}\text { Nilai tengah } \\
\text { populasi awal }\end{array}$ & $\begin{array}{c}\text { Nilai tengah } \\
\text { populasi terseleksi }\end{array}$ & $\begin{array}{c}\text { Differensial } \\
\text { Seleksi (\%) }\end{array}$ \\
\hline Tinggi Tanaman 45 HST $(\mathrm{cm})$ & 108,3 & 111,8 & 3,5 \\
Tinggi Tanaman 90 HST (cm) & 133,3 & 139,9 & 6,6 \\
Jumlah Anakan 45 HST & 23,1 & 22,8 & $-0,3$ \\
Jumlah Anakan 90 HST & 21,9 & 22,2 & 0,3 \\
Jumlah Anakan Produktif & 17,6 & 19,4 & 1,8 \\
Panjang Malai (cm) & 23,0 & 23,6 & 0,6 \\
Jumlah Gabah Bernas Malai-1 & 53,3 & 75,7 & 22,4 \\
Jumlah Gabah Hampa Malai-1 & 88,0 & 76,5 & $-11,6$ \\
Jumlah Gabah Total Malai-1 & 140,1 & 152,1 & 12,0 \\
Presentase Gabah Bernas Malai-1 & 0,4 & 0,5 & 0,1 \\
Bobot 100 Butir (g) & 1,6 & 1,7 & 0,1 \\
Bobot Gabah Bernas Malai Contoh-1 $(\mathrm{g})$ & 3,9 & 5,8 & 1,9 \\
Bobot Gabah Bernas Tanaman -1 $(\mathrm{g})$ & 14,5 & 22,4 & 7,9 \\
\hline
\end{tabular}

Nilai diferensial seleksi langsung berdasarkan karakter bobot gabah bernas per tanaman dapat dilihat pada Tabel 5. Hasil analisis data menunjukkan bahwa nilai tengah dari karakter bobot gabah bernas per tanaman meningkat menjadi 22,4 dengan diferensial seleksi sebesar 7,9. Seleksi yang dilakukan dalam pada penelitian ini meningkatkan nilai tengah karakter tinggi tanaman 45 HST, tinggi tanaman 90 HST, jumlah anakan produktif, panjang malai, jumlah gabah bernas per malai, jumlah gabah total per malai, bobot 100 butir, bobot gabah bernas per malai contoh, dan bobot gabah bernas per tanaman. Penurunan nilai tengah juga terjadi pada karakter jumlah anakan 45 HST sebesar 22,8 dengan deferensial seleksi sebesar 0,3 , serta karakter jumlah gabah hampa per malai sebesar 76,5 dengan deferensial seleksi sebesar 11,6 .

\section{KESIMPULAN}

Populasi F2 padi hasil persilangan IPB 4 S dan IR64 pada kondisi tercekam suhu tinggi memiliki nilai tengah lebih tinggi dari nilai tengah kedua tetua untuk beberapa karakter agronomi yang diamati dan terdapat segregan transgesif. Karakter agronomi yang diamati dikendalikan oleh gen aditif, epistasis duplikat, dominan, dan epistasis komplementer. Nilai heritabilitas arti luas untuk karakter agronomi yang diamati tergolong rendah sampai tinggi. Koefisien keragaman genetik yang diamati tergolong sempit sampai luas. Berdasarkan nilai heritabilitas yang tinggi dan koefisien keragaman genetik yang luas maka karakter panjang malai, persentase gabah bernas per malai, dan bobot gabah per malai contoh dapat dijadikan kriteria seleksi untuk seleksi generasi awal pemuliaan padi toleran cekaman suhu tinggi. Seleksi langsung berdasarkan jumlah gabah bernas per malai dengan intensitas 50\% menghasilkan diferensial seleksi $22.4 \%$ pada karakter bobot gabah bernas per tanaman.

\section{DAFTAR PUSTAKA}

Abdullah, B., S. Tjokrowidjojo, dan Sularjo. 2008. Perkembangan dan prospek perakitan padi tipe baru di Indonesia. Jurnal Litbang Pertanian 27:19.

Alnopri. 2004. Variabilitas genetik dan heritabilitas karakter-karakter pertumbuhan bibit tujuh genotipe kopi robusta-arabika. Jurnal ilmu Pertanian Indonesia 6(2):91-96.

Aryana, M. 2007. Uji Keseragaman, Heritabilitas dan Kemajuan Genetik Galur Padi Beras Merah Hasil Seleksi Silang Balik di Lingkungan Gogo. Jurnal Argonomi 12-20.

[BMKG] Badan Meteorologi Klimatologi dan Geofisika. 2015. Data iklim tahun 2015. Stasiun Klimatologi Darmaga. Bogor.

[BPS] Badan Pusat Statistik. 2015. Proyeksi Penduduk Menurut Provinsi 2010-2035. [Internet] [ diunduh 2015 Februari 4] tersedia pada http://www.bps.go.id/tab_sub/view.php?k at $=1 \&$ tabel=1\&daftar= $1 \&$ id_suby. 
Febrianto, E.B., Y. Wahyu, D. Wirnas. 2015. Keragaan dan keragaman genetik karakter agronomi galur mutan putatif gandum generasi m5. J. Agron. Indonesia 43(1):52-58.

Fehr, W.R. 1987. Principles of Cultivar Development: Theory and Technique. Vol.1. Macmillan Publishing, New York.

Griffiths, A.J.F., S.R. Wessler, R.C. Lewontin, W.M. Gelbart, D.T. Suzuki, J.H. Miller. 2005. Introduction to Genetic Analysis. WH Freeman, New York.

Haryono, S. K. 2001. Heritabilitas dan korelasi genotipe jemponan indeks panen dan indeks beberapa nomor contoh kecipir. Zuriat 22 (1):38-47.

Holland, J.B. 2001. Plant Breeding Rewiews. John Wiley and Sons, New Jersey.

IPCC. 2007: Climate Change 2007: Synthesis Report. Contribution of Working Groups I, II and III to the Fourth Assessment Report of the Intergovernmental Panel on Climate Change [Core Writing Team, Pachauri R.K and Reisinger A. (eds.)]. Geneva.

Jambormias, E. 2014. Analisis genetik dan segregasi transgresif berbasis informasi kekerabatan untuk potensi hasil dan panen serempak kacang hijau. Disertasi. Institut Pertanian Bogor. Bogor.

Klug, W.S., M.R. Cummings. 2005. Essentials of Genetics. International Ed. 5th Ed. Pearson Education, Inc. Upper Saddle River New Jersery, US.

Kuswanto, B. Guritno, L. Soetopo, A. Kasno. 2004. Pendugaan jumlah dan model aksi gen ketahanan kacang panjang (Vigna sesquipedalis L. Fruwirth) terhadap cowpea aphid borne mosaic virus. Jurnal Agrivita 26(3):262-270.

Kasno. 1992. Pemuliaan Tanaman Kacangkacangan. Balai Penelitian Tanaman Pangan. Malang.

[Kementan] Kementrian Pertanian. 2013. Statistik Pertanian Agricultural Statistics 2013. Kementerian Pertanian. Jakarta.
Kotak, S., J. Larkindale, U. Lee, P.K. Do ring, K.E. Vierling, K.D. Scharf. 2007. Complexity of the heat stress response in plants. Curr. Opin. Plant Biol. 10: 310-16.

Limbongan, Y.L. 2008. Analisis genetik dan seleksi genotip unggul padi sawah (oryza sativa 1.) Untuk adaptasi pada ekosistem dataran tinggi. Disertasi. Institut Pertanian Bogor. Bogor.

Makarim, A.K., E. Suhartatik. 2009. Morfologi dan Fisiologi Tanaman Padi. Badan Penelitian Tanaman Padi. Subang.

Manulu, V.M.P. 2016. Karakter agronomi dan marka SSR sebagai karakter seleksi generasi awal untuk toleransi suhu tinggi pada padi. Tesis. Institut Pertanian Bogor. Bogor.

Muhi, A.H. 2011. Pemanasan global (global warming). Jawa Barat (ID): IPDN. $\mathrm{Hlm}$ 1. [Internet] [ diunduh 2015 Februari 2] tersedia pada http://alimuhi.staff.ipdn.ac.id/wpcontent/uploads/2011/12/PEMANASANGLOBAL.pdf.

[2 Februari 2015].

Nasution, I., T. Suhartini. 1991. Evaluasi metode uji ketahanan kultivar padi gogo terhadap tanah masam.

Prosiding Lokakarya Penelitian Komoditas dan Studi Khusus, 65-80. Bogor 13 Mei 1991. Machmud M., Kosim Kardin M. dan Gunarto L. (Ed.). Badan Penelitian dan Pengembangan Pertanian. Departemen Pertanian.

Peng, S., J. Huang, J.E. Sheehy, R.C. Laza, R.M.Visperas, X. Zhong, G.S. Centeno, G.S. Khush, K.G. Cassman. 2004. Rice yield decline with higher night temperature from global warming. In E.D. Redona, A.P. Castro \& G.P. Llanto, eds. Rice Integrated Crop Management: Towards a Rice Check syatem in the Philippines: 46-56. Nueva Ecija, Philippines.

Poehlman, J. M., D. Sleeper. 1996. Breeding Field Crops. Iowa State University Press. Iowa.

Puspitasari, W. 2011. Pendugaan parameter genetik dan seleksi karakter agronomi 
dan kualitas sorgum di lahan masam. Tesis. Institut Pertanian Bogor. Bogor.

Roy, D. 2000. Plant Breeding: Analysis and Exploitation of Variation. Narosa Publishing House. Calcutta. Rusdi E. dan Bahar H.1999. Kontribusi karakter agronomi dan komponen hasil terhadap perbaikan padi sawah dataran tinggi. Jurnal Stigma VII (I): 16-20. Fakultas Pertanian UNAND. Padang.

Subagyono, K., E. Surmaini. 2007.Pengelolaan sumberdaya iklim dan air untuk antisipasi perubahan iklim. Jurnal Meteorologi dan Geofisika 8(1):27-41.

Suhartatik, E., A.K. Makarim, R. Tita. 2008. Pertumbuhan dan Produktivitas Padi Sawah di Tanah Ultisol Sukamandi pada Dua Musim Tanam. Balai Besar Penelitian Tanaman Padi. Subang.

Suwedi, N. 2005. Upaya pencegahan dan penanggulangan dampak pemanasan global. J. Tek. Ling. 6(2):397- 401.

Syukur, M., S. Sujiprihati, A. Siregar. 2010. Panduan parameter genetik beberapa karakter agronomi cabai F4 dan evaluasi daya hasilnyamenggunakan rancangan perbesaran (augmented design). Jurnal Agrotropika (15)1:9-16.

Syukur, M., S. Sujiprihatini, R. Yunianti. 2015. Teknik Pemuliaan Tanaman: Edisi Revisi. Penebar Swadaya, Depok.

Tschirley, J. 2007. Climate Change Adaptation: Planning and Practices. Power Point Keynote Presentation of

FAO Environment, Climate change, Bioenergy Division, 10-12 September 2007. Rome.

Wahid, A., S. Gelani, M. Ashraf, M.R. Foolad. 2007. Heat tolerance in plants: an overview, Environ. Exp.

Bot. 61:199-223.

Wirnas, D., I. Widodo, Sobir, Trikoesoemaningtyas, D. Sopandie. 2006. Pemilihan karakter agronomi untuk menyusun indeks seleksi pada 11 populasi kedelai generasi F6. Bul. Agron. 34(1):19-24. 